УДК 619:591.145:612.398.192:636.7, DOI 10.31210/visnyk2018.02.24

(C) 2018

\author{
Цвіліховський М. І., доктор біологічнихнаук, професор, \\ Якимчук О. М., кандидат біологічних наук, \\ Іванченко Н. Ю., аспірант
}

Національний університет біоресурсів і природокористування України

\title{
МЕТАБОЛІЧНА ТЕРАПІЯ НА ОСНОВІ АМІНОКИСЛОТ ЗА ЕПІЛЕПСІЇ У СОБАК. КОМПЕНСАТОРНА ЗДАТНІСТЬ ОРГАНІЗМУ ЯК ПРИЧИНА ОБМЕЖЕНОГО ПЕРІОДУ КЛІНІЧНОЇ ЕФЕКТИВНОСТІ
}

\section{Рецензент - доктор ветеринарних наук С. П. Долецький}

Епілепсія є найбільш поширеним хронічним неврологічним захворюванням як серед людей, так $і$ серед тварин. Діагностика і терапія епілепсії є непростим завданням як у гуманній, так і у ветеринарній медицині.

У статті наведено результати дослідження щзодо ефективності амінокислот лейцину, ізолейцину, валіну, гліцину і таурину за їх одночасного перорального застосування собакам, хворим на епілепсію невідомого походження. Встановлено зміни молярних співвідношень вільних амінокислот у сироватці крові хворих на епілепсію собак до і після початку метаболічної терапії та теоретично обтрунтовано причину обмеженого періоду ефективності протиепілептичної дї вказаних амінокислот у собак.

Ключові слова: собаки, епілепсія, компенсаторна здатність, амінокислоти, електроенцералографія.

Постановка проблеми. Епілепсія є комплексним захворювання головного мозку, яке проявляється раптовою аномальною активністю, що обумовлює клінічну симптоматику епілептичних нападів (зазвичай тривалістю менше 2-3 хвилин), які характеризуються моторними, вегетативними та/чи поведінковими змінами (згідно IVETF) [5].

Поширеність епілепсії у популяції собак за різними даними становить від $0,5 \%$ до $5 \%$ [5].

Не дивлячись на значний світовий досвід у лікуванні дрібних тварин за епілепсії, розробка нових лікарських засобів і методів терапії цієї патології залишається актуальною [8].

Ефективність та безпечність переважної більшості протиепілептичних лікарських засобів $\epsilon$ недостатньою. В третини хворих на епілепсію собак розвивається фармакорезистентність незалежно від обраного для лікування препарату [8].

Переважна більшість протиепілептичних препаратів, які використовуються для лікування собак за епілепсії (фенобарбітал, натрію та калію бромід, фелбамат та інші), $€$ хімічносинтезованими, чужорідними для організму сполуками, що мають велику кількість побічних ефектів. Найбільш поширеними 3 них є седація, атаксія, поліфагія, полідипсія, поліурія, підвищення активності ферментів печінки та інших органів, що беруть участь у метаболізмі протиепілептичних препаратів [3]. Такі дані є причиною, яка спонукає до розробки нових, безпечніших у використанні препаратів.

У сучасній гуманній медицині активно розвивається концепція метаболічної терапії, що передбачає, в тому числі, використання амінокислот 3 лікувальною метою $[2,9]$. В раніше опублікованій нами статті [1] ми продемонстрували ефект терапії на основі амінокислот: валіну, лейцину, ізолейцину, гліцину та похідного амінокислоти цистеїну таурину у хворих на епілепсію собак. Однак, протиепілептичний ефект виявився транзиторним. В даній статті ми ставили за мету дослідити та обгрунтувати причини короткочасності протиепілептичної терапії.

Аналіз останніх досліджень і публікацій 3 даної проблеми. Проблемі дослідження епілепсії у собак, а також впровадження метаболічної терапії для іiі лікування присвятили свої праці низка вітчизняних та зарубіжних дослідників. Зокрема, у своїх працях М. І. Цвіліховський, О. М.Якимчук та Н. Ю. Іванченко експериментальним шляхом встановили терапевтичну ефективність комплексу амінокислот у хворих за епілепсії собак [1]. У своїй праці A. Evangeliou, M. Spilioti та V. Doulioglou дослідили вплив амінокислот з розгалуженими ланцюгами у терапії кетогенної дієти при епілепсії [2]. C. V. Dewey провів дослідження антиконвульсивної терапії у собак та котів [3]. Біології мозкових дисфункцій у тварин присвячена праця G. E.Gaull [4]. Питанням визначення, класифікації та термінології епілепсії у супутніх тварин займалися дослідники M. Berendt, R. G. Farquhar та P. J. Mandigers [5]. T. Ishikawa дослідив співвідношення в організмі тварин тирозину до інших амінокислот при захворюваннях головного мозку [6]. Нові аспекти стосовно подолання гематоенцефалічних ба- 


\section{ВЕТЕРИНАРНА МЕДИЦИНА}

p'єрів у своїй праці було описано S. Ohtsuki [7]. Профілактику епілепсії у тварин шляхом застосування таурину дослідили F. Junyent, J. Utrera та R. Romero [8]. C. W. Dewey, R. Guiliano та D. M. Boothe описали амінокислотну терапію за епілепсії у собак [9].

Мета роботи. Метою роботи було встановити та проаналізувати зміни, що відбуваються в амінокислотному пулі крові хворих на епілепсію собак за екзогенного надходження до їх огранізму наднормових доз амінокислот, а також обгрунтувати короткочасність періоду протиепілептичної ефективності терапії на основі амінокислот.

Матеріали і методи досліджень. Дослідження проводились в умовах клініки дрібних тварин НУБіП України, клініки ветеринарної медицини «БіоСфера» (м. Київ), клініки ветеринарної медицини «Велика Ведмедиця» (м. Київ). До дослідної групи було включено 8 собак, які належали власникам, із генералізованими та вторинногенералізованими епілептичними нападами, яким на основі результатів клінічних, лабораторних (клінічний аналіз крові та сечі, біохімічний аналіз сироватки крові, загальний аналіз ліквору, імуноферментний аналіз сироватки крові та ліквору щодо чуми м'ясоїдних, лептоспірозу, герпесу I та II типів, токсоплазмозу, неоспорозу, бореліозу та бруцельозу) й інструментальних досліджень та 3 урахуванням даних анамнезу було встановлено діагноз «епілепсія невідомого походження» (згідно класифікації IVETF; раніше «криптогенна епілепсія», «ймовірно симптоматична епілепсія») [5]. Собаки були представлені породами американський бульдог, доберман, російський чорний тер'єр, німецька вівчарка, французький бульдог (2) та метис (2) віком 1-7 років. Кількість самців склала 5 особин (4 із них нестерилізовані), самок -3 особини (нестерилізовані). Тривалість інтеріктальних періодів становила 4-10 діб.

Контрольна група тварин була сформована із клінічно здорових собак-метисів віком 2-3 роки.

За 10 діб до початку дослідження тварини були переведені на повнораціонний корм «Brit» компаніï «Brit PetFood» (Чехія), який задавався згідно 3 рекомендаціями виробника. Ефективність терапії контролювали, в тому числі, з урахування даних електроенцефалографії [1].

Визначення вмісту амінокислот у сироватці крові собак проводили в умовах лабораторії «Група хроматографії» Інституту біохімії ім. О.В.Палладіна НАН України методом іонообмінної рідинно-колонкової хроматографії за допомогою автоматичного аналізатора амінокислот «Т 339» виробництва Чехії.
Дослідження вмісту вільних амінокислот у сироватці крові собак контрольної групи проводили на початку досліду, через 1 та через 2 місяці після початку метаболічної терапії, собак контрольної групи - на початку досліду одноразово. Відбір крові для визначення вмісту вільних амінокислот на початку досліду проводили зранку до годівлі; під час досліду - зранку, через 8 годин після останнього задавання амінокислотного композиту. Кров у собак відбирали з латеральної підшкірної вени (v. cephalica) безпосередньо у центрифужну пробірку. Зразки крові залишали за кімнатної температури до повного утворення згустку після чого центрифугували протягом 15 хв при 3000 об./хв. Отриману після центрифугування крові сироватку піддавали депротеїнізації для одержання екстракту вільних амінокислот. Депротеїнізацію проводили сульфосаліциловою кислотою наступним чином: 1 мл сироватки крові поміщали у центрифужну пробірку, додавали 1 мл 3\%-го водного розчину сульфосаліцилової кислоти і ретельно перемішували. Білок, що випав, відокремлювали центрифугуванням при 4000 об./хв, протягом 30 хв. Отриману таким чином надосадову рідину (супернатант) наносили на іонообмінну колонку амінокислотного аналізатора та проводили визначення вмісту вільних амінокислот згідно інструкції до автоматичного аналізатора амінокислот «Т 339».

Комплекс амінокислот задавали собакам перорально у вигляді капсульованої лікарської форми у таких добових дозах: L-лейцин («Myprotein», Beликобританія) - 150 мг/кг, L-ізолейцин («Ajinomoto», Японія) - 275 мг/кг; L-валін («Ajinomoto», Японія) - 240 мг/кг; гліцин («Биотики», Росія) 300 мг/кг; таурин («Olimp sport nutrition», Польща) - 240 мг/кг. Добову дозу ділили порівно на 3 прийоми та задавали кожних 8 годин після годівлі протягом двох місяців.

Результати проведених дослідів у вигляді цифрових даних були оброблені статистично за допомогою програми Microsoft Office Excel, оцінюючи вірогідність показників ( $\mathrm{p} \leq 0,05, \mathrm{p} \leq 0,01$, $\mathrm{p} \leq 0,001)$ за критерієм Стьюдента.

Результати досліджень. Через місяць від початку метаболічної терапії у сироватці крові хворих на епілепсію собак достовірно збільшився вміст як амінокислот, що задавалися з терапевтичною метою, так і деяких інших амінокислот (серин, глутамінова кислота, аланін, гістидин, аргінін). Загалом тенденція до підвищення вмісту спостерігалася по відношенню до всіх досліджуваних нами амінокислот.

Через 2 місяці метаболічної терапії тенденція до підвищення рівня амінокислот та їх похідних 


\section{ВЕТЕРИНАРНА МЕДИЦИНА}

у сироватці крові хворих на епілепсію собак зберігалася. Проте достовірним (порівняно 3 результатами, що були отримані нами після першого місяця лікування собак) у цьому випадку було підвищення вмісту фенілаланіну, глутамінової кислоти, метіоніну, треоніну, глутаміну, проліну, аргініну, аланіну, тирозину, гістидинута орнітину [1].

Тривалість періоду ефективності метаболічної терапії, однак, була не довготривалою і склала 35-48 діб. На нашу думку, причиною зникнення терапевтичного ефекту стало повернення масових часток амінокислот, що задавалися з лікувальною метою, до попередніх значень внаслідок компенсаторних процесів білкового обміну.

Відомо, що важливіше значення має не абсолютний вміст амінокислот в органах та рідинах організму, а їх співвідношення між собою [7]. Це пов'язано 3 конкурентними властивостями амінокислот при використанні транспортних систем організму, а також із необхідним їх співвідношенням для перебігу біохімічних реакцій.

Для отримання терапевтичного ефекту за застосування лейцину, ізолейцину, валіну, гліцину i таурину в якості антиконвульсантів, необхідною умовою $є$ підвищення їх частки по відношенню до інших амінокислот, з якими вони перебувають у конкурентних відносинах щодо використання транспортних систем, відповідальних за перенесення вільних амінокислот через ГЕБ та щодо участі в інших процесах обміну.

При проведенні досліджень із вивчення обміну амінокислот в організмі широко застосовується розрахунок молярних співвідношень між окремими амінокислотами чи їх групами [6]. 3 огляду на це, нами на основі узагальнених даних, отриманих у групі хворих на епілепсію собак на різних етапах експериментальних досліджень, були визначені зміни у співвідношеннях амінокислот сироватки крові до початку лікування, через 1 та 2 місяці від початку лікування собак.

Особливу увагу ми приділили оцінці часток амінокислот із розгалуженим бічним ланцюгом лейцину, ізолейцину та валіну, по відношенню до конкурентних їм ароматичних амінокислот, а також метіоніну і треоніну. Наша зацікавленість щодо масових часток саме лейцину, ізолейцину і валіну була зумовлена тим, що їх надходження до центральної нервової системи відбувається шляхом транспорту за допомогою транспортної системи L гематоенцефалічного бар'єру (ГЕБ), за використання якої вони конкурують $з$ ароматичними амінокислотами, метіоніном і треоніном. Натомість таурин, використовуючи для транспорту через ГЕБ транспортну систему TAUT, не має специфічних антагоністів (амінокислот чи будь-яких інших сполук), а гліцин надходить до ЦНС через гематоенцефалічний бар'єр за допомогою білків-переносчиків, а також пасивно через гематоенцефалічний та гематолікворний бар'єри. Крім того у перенесенні гліцину значну роль відіграє везикулярна система транспорту ГАМК [7].

Після першого місяця лікування собак частка амінокислот із розгалуженими бічними ланцюгами по відношенню до конкурентних їм амінокислот значно підвищилася, порівняно з результатами, отриманими до початку лікування цих тварин. У той же час, результати, що були отримані нами через 2 місяці метаболічної терапії собак, демонструють добре виражену тенденцію до відновлення попередніх співвідношень.

Дисбаланс амінокислот, що виникає за підвищеного надходження однієї чи декількох амінокислот, призводить до зростання активності ферментів (особливо амінотрансфераз печінки), яке підвищує інтенсивність катаболізму та анаболізму білків. Це проявляється більш швидким насиченням амінокислотного пулу вільними амінокислотами. Саме цим обумовлено зростання вмісту всіх вільних амінокислот у сироватці крові собак, що спостерігалося в нашому дослідженні. Підвищення активності ферментів у мозку не відбувається, тобто рівень амінокислот у нервовій системі залежить від складу амінокислотного пула крові [4].

Частка лейцину в сироватці крові хворих на епілепсію собак через місяць від початку їх лікування зросла відносно всіх досліджуваних нами амінокислот та їх похідних. Виключенням $є$ таурин, відносно якого частка лейцину зменшилася на 8,3\%, та гліцин, відносно якого частка лейцину залишилася незмінною. Особливо виражене зростання частки лейцину спостерігалося відносно фенілаланіну, метіоніну, цистину і орнітину. Так, відносно фенілаланіну вона зросла в 2,03 раза, цистину - в 1,89 , орнітину - в 1,87 i метіоніну - в 1,82 раза. Відносно тирозину частка лейцину зросла у 1,76 раза, глутаміну - в 1,73, треоніну - в 1,7 , проліну - в 1,67 , лізину - в 1,65 , аспарагінової кислоти - в 1,57 і аргініну - в 1,51 раза.

Зростання частки лейцину відносно ізолейцину, валіну, аланіну, серину та глутамінової кислоти було менш вираженим. Так, відносно аланіну частка лейцину зросла на 45,5 \%, глутамінової кислоти - на 26,2 \%, валіну - на 10,5 \%, ізолейцину - на 9,7 \%, серину - на 3,5 \% (рис. 1). 


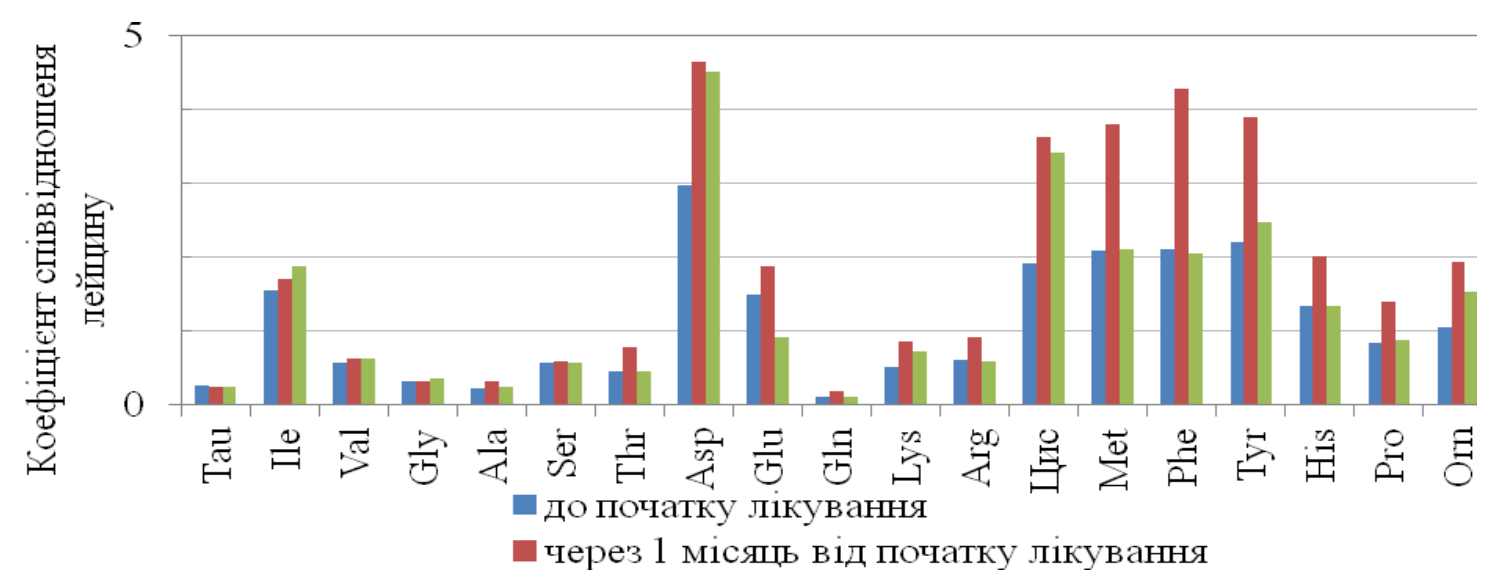

Рис. 1. Молярне відношення лейцину до інших амінокислот та ӥх похідних у сироватці крові хворих на епілепсію собак до, через 1 та 2 місяці лікування

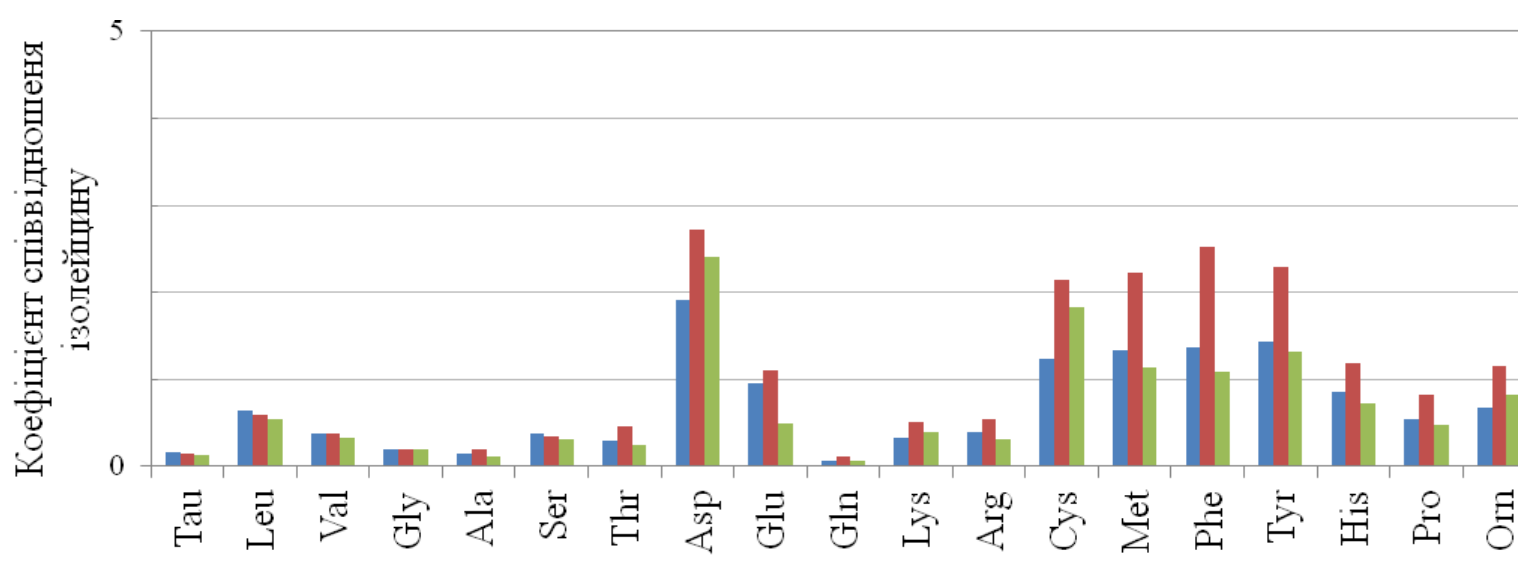

до початку лікування

через 1 місящь від початку лікування

через 2 місяці від початку лікування

\section{Рис. 2. Молярне відношення ізолейцину до інших амінокислот та їх похідних у сироватці} крові хворих на епілепсію собак до, через 1 та 2 місяці лікування

Через 2 місяці метаболічної терапії частка лейцину відносно ізолейцину та гліцину зросла ще на $10 \%$ та $13 \%$ відповідно, порівняно із значеннями, отриманими до початку лікування собак. Відносно глутамінової кислоти та аргініну частка лейцину знизилася на $62 \%$ і 5,2\%, відповідно, порівняно зі значенням до початку лікування собак. Показники співвідношення лейцину до аланіну, серину, треоніну, глутаміну, метіоніну, фенілаланіну тирозину, гістидину та проліну майже повернулися до попередніх значень. Відносно лізину, орнітину, аспарагінової кислоти та цистину частка лейцину знизилася, проте вона була вищою на $40,4 \%, 47 \%, 52,4 \%$ та $78 \%$, відповідно, порівняно 3 результатами, отриманими до початку лікування собак (рис. 1).

Через місяць від початку терапії частка ізолейцину в сироватці крові хворих на епілепсію собак зросла відносно треоніну в 1,53 , лізину - в 1,55 , проліну - в 1,54 , глутаміну - в 1,57 , тирозину - в 1,61 , цистину - в 1,73 , метіоніну - в 1,66 , орнітину - в 1,72 та фенілаланіну - в 1,84 раза (рис. 2).

Частка ізолейцину відносно аспарагінової кислоти зросла на 42,9 \%, гістидину - на $37,2 \%$, аланіну - на 35,7 \%, глутамінової кислоти - на $15,6 \%$. Частка ізолейцину відносно валіну залишилася незмінною, в той час, як відносно таурину, лейцину, серину та гліцину вона знизилася на $21,4 \%, 10,2 \%, 5,7 \%$ та 5,3\% відповідно.

Через 2 місяці від початку метаболічної терапії собак частка ізолейцину майже повернулася до попередніх значень порівняно 3 аланіном, глутаміном, лізином та аргініном (рис. 2). 


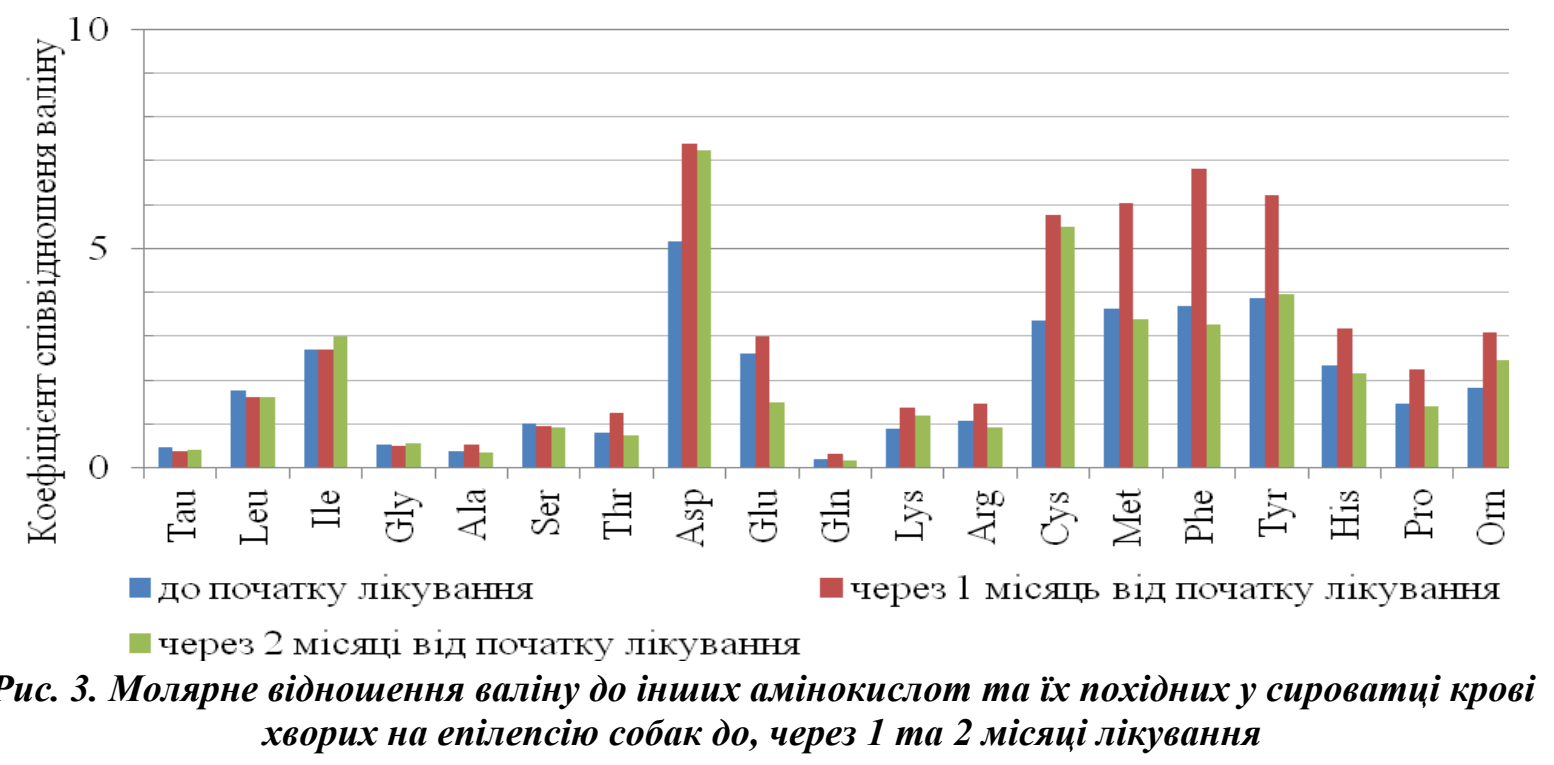

Менш виражена тенденція до відновлення попередніх значень спостерігалася відносно аспарагінової кислоти, цистину та орнітину. Відбулося подальше зниження частки ізолейцину в сироватці крові собак відносно таурину, лейцину та серину на 7,7 \%, 9,3 \%, 12,9 \% відповідно, порівняно з результатами, отриманими через місяць від початку лікування тварин. Крім того, частка лейцину відносно валіну знизилася на $12 \%$, а відносно гліцину залишилася незмінною, порівняно зі значеннями, отриманими через місяць від початку метаболічної терапії собак. Частка ізолейцину зменшилася, порівняно з результатами до лікування собак, відносно глутамінової кислоти в 2 рази, фенілаланіну - на $25,7 \%$, треоніну - на $25 \%$, гістидину $19,4 \%$, метіоніну - на 18,6 \%, проліну - на 14,9\%, тирозину - на $8,3 \%$.

Частка валіну через місяць від початку метаболічної терапії відносно фенілаланіну зросла в 1,84 раза, цистину - в 1,72, орнітину - в 1,69 раза, метіоніну - в 1,66, глутаміну - в 1,63, тирозину - в 1,61, треоніну - в 1,56, проліну - в 1,53 і лізину - в 1,52 раза, а відносно аспарагінової кислоти - на 43 $\%$, аргініну - на $37,4 \%$, гістидину - на $36,5 \%$, аланіну - на 33,3\%, глутамінової кислоти - на $15 \%$. Частка валіну відносно ізолейцину не змінилася. Зменшення частки валіну спостерігалося у випадку таурину - на $21 \%$, лейцину - на 9,4 \%, гліцину на $8 \%$ і серину - на $6,4 \%$ (рис. 2).

Через 2 місяці лікування собак частка валіну відносно ізолейцину зросла на $10,7 \%$, відносно таурину та лейцину суттєвих змін не відбулося, а відносно гліцину, аланіну, глутаміну та тирозину вона повернулася до попередніх значень (рис. 3).

Менш вираженою була тенденція до віднов- лення співвідношення валіну, встановленого до початку лікування собак, у випадку лізину, орнітину, аспарагінової кислоти та цистину, частка валіну відносно яких залишалася вищою на 31 , 33,9; 40 та 63 \% відповідно, порівняно з результатами, отриманими до початку лікування тварин. Частка валіну відносно серину зменшилася ще на 2,2 \%, порівняно з першим місяцем терапії. Частка валіну відносно глутамінової кислоти зменшилась в 1,8 раза, аргініну - на $15 \%$, фенілаланіну - на $13 \%$, треоніну - на 9,6\%, гістидину - на $8 \%$, метіоніну - на 7,4 \%, проліну - на $3,5 \%$ порівняно $з$ даними, отриманими до початку лікування собак.

Через місяць від початку лікування частка гліцину відносно фенілаланіну зросла в 1,99 раза, цистину - в 1,85 , орнітину - в 1,83 , метіоніну - в 1,79 , глутаміну - в 1,74 , тирозину - в 1,74 , треоніну - в 1,68, проліну - в 1,65, лізину - в 1,63 , аргініну - в 1,49, гістидину - в 1,48 і аланіну - в 1,41 раза. Частка гліцину по відношенню до глутамінової кислоти, валіну та ізолейцину зросла на 24,$3 ; 8,1$ та $8 \%$ відповідно, тоді як відносно серину змін не відбулося. Зниження частки гліцину спостерігалося відносно таурину та лейцину - на 13,3 та $2 \%$ відповідно (рис. 4).

Через 2 місяці відбулося майже повне відновлення частки гліцину відносно глутаміну та тирозину. Менш виражена тенденція до відновлення спостерігалася у випадку ізолейцину, лізину, орнітину, аспарагінової кислоти та цистину, частка гліцину відносно яких залишалася вищою на 7, 25,7, 29, 35 та 35 \% відповідно, порівняно 3 результатами, отриманими до початку лікування собак. 


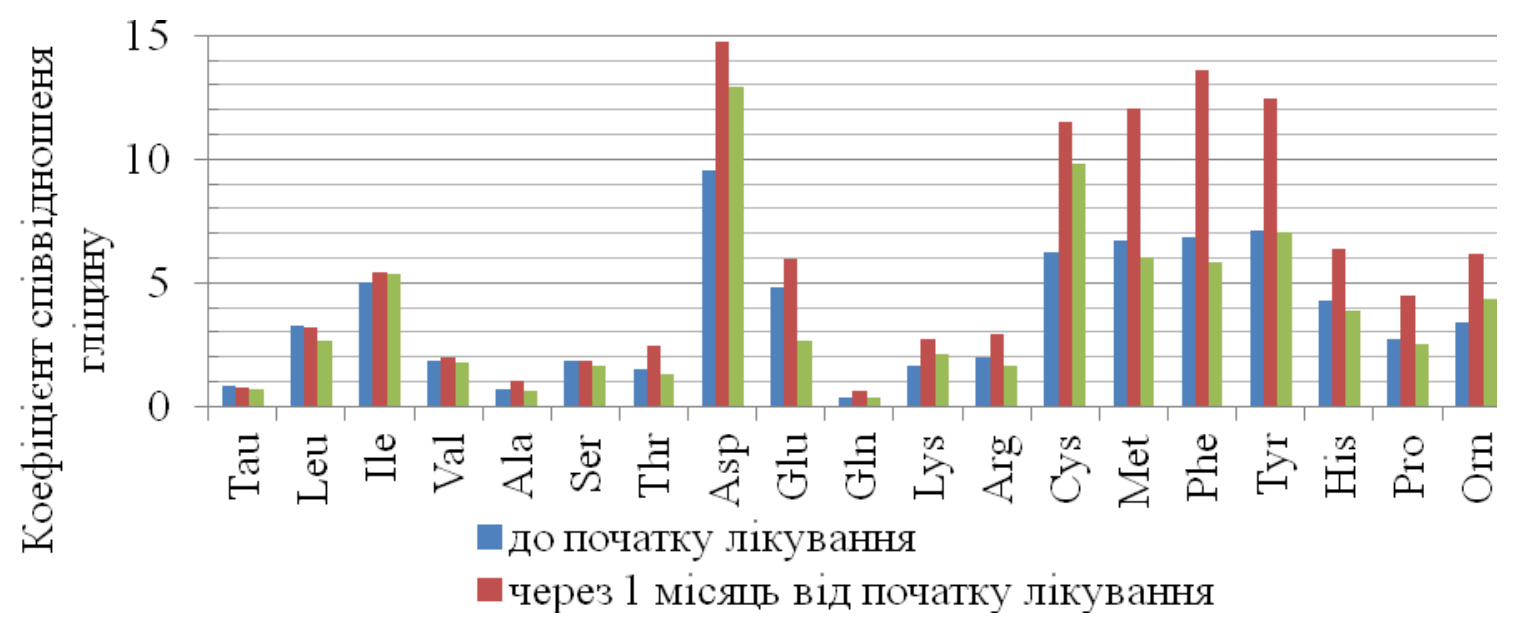

Рис. 4. Молярне відношення гліцину до інших амінокислот та їх похідних у сироватці крові хворих на епілепсію собак до, через 1 та 2 місяці лікування

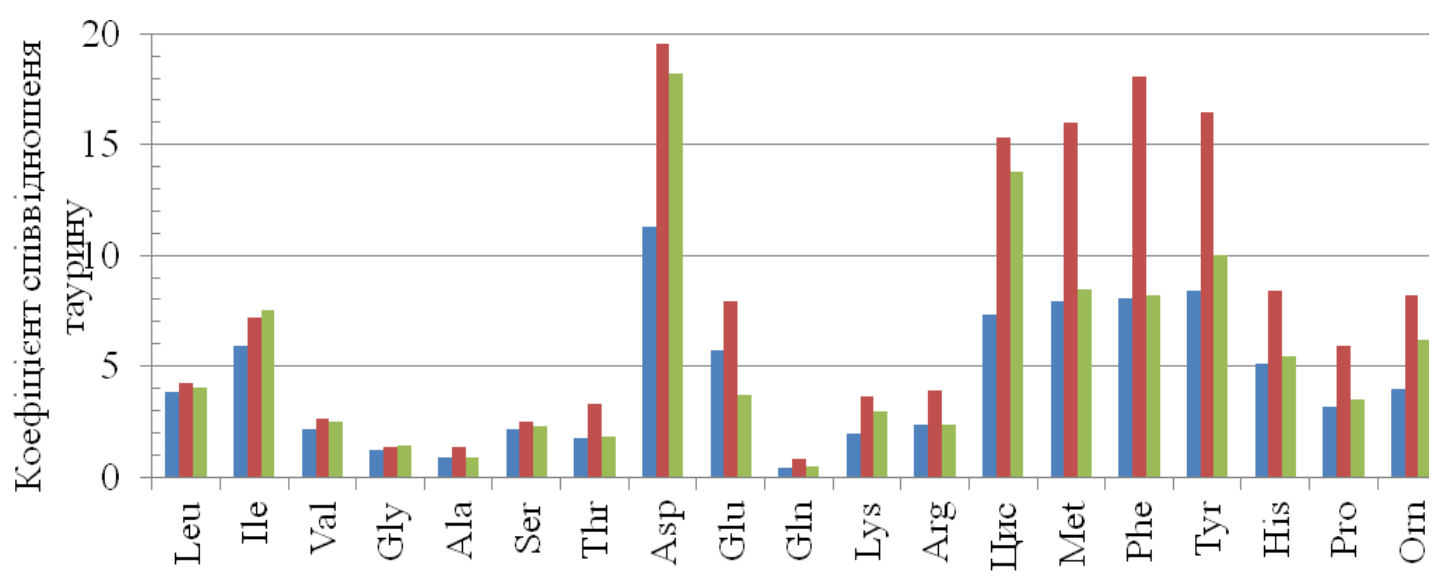

шо початку лікування

перез 1 місящ від початку лікування

через 2 місящі від початку лікування

Рис. 5. Молярне відношення таурину до інших амінокислот та ӥх похідних у сироватці крові хворих на епілепсію собак до, через 1 та 2 місяці лікування

Подальше зниження частки гліцину спостерігалося відносно лейцину і таурину на 20 та 5,6 \% відповідно, порівняно 3 даними, що були отримані до початку метаболічної терапії тварин. На 11,5 \% знизилась також частка гліцину відносно серину.

Крім того, відбулося зниження частки гліцину відносно інших амінокислот порівняно з результатами до початку метаболічної терапії собак. Так, відносно глутамінової кислоти частка гліцину знизилася в 1,8 раза, аргініну - на $18,7 \%$, фенілаланіну - на $17,2 \%$. Зниження частки гліцину відносно інших амінокислот було менш вираженим і коливалося в межах 4-14 \% (рис. 4).

Через місяць від початку терапії в сироватці крові хворих на епілепсію собак частка таурину зросла порівняно із вмістом всіх досліджуваних нами амінокислот та їх похідних, у тому числі до застосовуваних собакам амінокислот при проведенні таурином метаболічної терапії, а саме відносно лейцину, ізолейцину, валіну та гліцину. Найбільш виражене зростання частки таурину спостерігалося відносно метіоніну, цистину, орнітину та фенілаланіну - в 2,02, 2,08, 2,06, та 2,24 раза відповідно, а відносно аспарагінової кислоти, лізину, проліну, треоніну, глутаміну та тирозину - в $1,74,1,84,1,85,1,88,1,93$, та 1,96 раза відповідно. Частка таурину відносно аргініну зросла на $67 \%$, гістидину - на $65,7 \%$, аланіну - на 59,3\%, глутамінової кислоти - на 39,8\%. Зростання вмісту таурину відносно інших амінокислот було менш вираженим і коливалося в межах 10,5-21,6 \% (рис. 5).

Через 2 місяці від початку метаболічної тера- 


\section{ВЕТЕРИНАРНА МЕДИЦИНА}

пії спостерігалася тенденція до відновлення попередніх співвідношень, за виключенням ізолейцину та гліцину. Так, частка таурину відносно цих амінокислот зросла ще на 5,2 та 6 \% відповідно, порівняно 3 результатами, отриманими через місяць від початку метаболічної терапії собак. Співвідношення вмісту таурину до вмісту аланіну, треоніну, глутаміну, аргініну, метіоніну, фенілаланіну, тирозину, гістидину та проліну майже повернулися до попередніх значень.

Частка таурину відносно серину, валіну, лізину, орнітину, аспарагінової кислоти та цистину знизилася, проте залишалася вищою на 8,3\%, $15 \%, 49,7 \%, 54,9 \%, 61,3 \%$ та 87,9\%, відповідно, порівняно 3 результатами, отриманими до початку лікування собак. Частка таурину відносно глутамінової кислоти значно знизилася і була на 52,7 \% нижчою, ніж до початку метаболічної терапії собак.

На нашу думку, це обумовлено компенсаторними реакціями організму собак, що призводять

\section{БІБЛІОГРАФІЯ}

1. Цвіліховський М. І., Якимчук О. М., Іванченко Н. Ю. Терапевтична ефективність комплексу амінокислот у хворих за епілепсії собак // Науковий вісник Національного університету біоресурсів і природокористування України. Серія "Ветеринарна медицина, якість і безпека продукції тваринництва". - 2016. - Вип. 237. С. 206-216.

2. Branched chain amino acids as adjunctive therapy to ketogenic diet in epilepsy: pilot study and hypothesis. / [A. Evangeliou, M. Spilioti, V. Doulioglou та ін.]. // J Child Neurol. - 2009. - №4. C. 1268-1272.

3. Dewey $C$. $V$. Anticonvulsant therapy in dogs and cats / Dewey. // Vet Clin North Am Small Anim Pract. - 2006. - №36. - C. 1107-1127.

4. Gaull G. E. Biology of Brain Dysfunction. Vol.3 / Gerald Gaull. - New York: Plenum Press, 1975. - $486 \mathrm{c}$.

5. International veterinary epilepsy task force consensus report on epilepsy definition, classification and terminology in companion animals [Internet

\section{ANNOTATION}

Tsvilikhovskyi M. I., Yakymchuk O. M., Ivanchenko N. Yu. Amino acids based on metabolic therapy in epileptic dogs. Organisms' compensatory ability as the reason of limited clinical efficacy.

The epilepsy is the most widespread chronic neurological disorders among animals, as well as до часткової стабілізації молярних співвідношень вільних амінокислот в амінокислотному пулі крові і, відповідно, відновлення фізіологічних співвідношень амінокислот, які надходять у нервову систему.

Висновок. Комплекс амінокислот лейцину, ізолейцину, валіну, гліцину і таурину при пероральному задаванні хворим на епілепсію невідомого походження собакам володіє протиепілептичною ефективністю, яка клінічно проявляється подовженням інтеріктального періоду в 2-3 рази у $37,5 \%$ хворих собак.

Короткотривалий період ефективності метаболічної терапії (35-48 діб) зумовлений компенсаторними реакціями організму собак у відповідь на понаднормове екзогенне надходження амінокислот.

На нашу думку, подальші дослідження щодо протиепілептичних властивостей амінокислот у собак є перспективними і заслуговують на увагу.

source] / [M. Berendt, R. G. Farquhar, P. J. Mandigers et al.] // BMC Veterinary Research. - 2015. Retried from http://argos.portalveterinaria.com/ pdf/international_veterinary_epilepsy_task_force consensus_report_on_epilepsy_2015.pdf.

6. Ishikawa T. Branched-chain amino acids to tyrosine ratio value as a potential prognostic factor for hepatocellular carcinoma / Ishikawa. // World J Gastroenterol. - 2012. - №18. - C. 2005-2008.

7. Ohtsuki S. New aspects of the blood-brain barrier transporters; its physiological roles in the central nervous system / Ohtsuki. // Biological \& Pharmaceutical Bulletin. - 2004. - C. 1489-1496.

8. Prevention of Epilepsy by Taurine Treatments in Mice Experimental Model / [F. Junyent, J. Utrera, R. Romero et al.]. // Journal of Neuroscience Research. - 2009. - №87. - C. 1500-1508.

9. Zonisamide therapy for refractory idiopathic epilepsy in dogs / [C. W. Dewey, R. Guiliano, D. M. Boothe et al.]. // J Am AnimHosp Assoc. - 2004. №40. - C. 285-291.

among people.

According to scientific literature such amino acids, as leucine, isoleucine, valine, glycine and taurine appears to be promising regarding antiepileptic effect.

The aim of our investigation was to estimate the 


\section{ВЕТЕРИНАРНА МЕДИЦИНА}

ability of amino acid mixture to prevent epileptic seizures in dogs and to analyze changes that take place in the blood amino acid pool of this species in case of exogenous amino acid overload.

Eight dogs of different breeds with which were diagnosed as such that had probably symptomatic epilepsy («unknown cause epilepsy», IVETF) were engaged in the experiment.

During 2 months of the experiment the dogs received amino acids orally in such daily doses per kilogram divided equally in order to be given every 8 hour: L-leucine $-150 \mathrm{mg}$, L-isoleucine $-275 \mathrm{mg}$; L- valine - $240 \mathrm{mg}$; glycine $-300 \mathrm{mg}$; taurine -240 mg.

The efficacy was estimated by visual detection of paroxysmal activity and quantitative electroencephalography using fast Fourier transformation to the frequency range of bands corresponding 0.5-3.0 $\mathrm{Hz}$ for delta, 4.0-7.0 Hz for theta, 8.0-13.0 Hz for alpha and $\beta 14.0-40.0 \mathrm{~Hz}$ for beta bands.

The detection of the concentration of amino acids in serum and cerebrospinal fluid was performed by ion exchange liquid chromatography.

Sick dogs demonstrated higher frequency ranges of delta, theta and alpha bands and lower frequency range of beta band comparing to healthy dogs. After one-month treatment the frequency ranges of delta, theta and alpha bands lowered whereas the frequency of beta band became higher. Clinically antiepileptic effect of amino acid composition was represented by the prolongation of interictal periods per 2 to 3 times.

After one month treatment the amount of BCAA in serum increased as well as the amount of other amino acids. Also the molar ratio of serum acids was changed. The concentration of such amino acids as leucine, glycine, taurine and serine in cerebrospinal fluid was increased.

After the second month of treatment the tendency to serum amino acid ratio stabilization was noticed.

The period of efficacy was short (approximately 35-48 days). To our opinion it is due to compensatory mechanisms of protein metabolism that were represented by partial amino acid molar ratio stabilization.

The complex of L-leucine, L-isoleucine, L-valine, glycine and taurine possesses the anticonvulsant activity in $37,5 \%$ of cases when being given orally to dogs with probably symptomatic epilepsy. The brief period of efficacy of such metabolic therapy is due to compensatory processes which take place in dogs' organisms. Further investigations regarding amino acids' anticonvulsant properties in dogs seam to be perspective and should be carried out.

Key words: dogs, epilepsy, compensatory ability, amino acids, electroencephalography. 